\title{
Schistosomiasis mansoni in urban Northeast Brazil: influence of rainfall regime on the population dynamics of Biomphalaria sp.
}

\author{
Daniel Santos Oliveira ${ }^{[1]}$, Vanessa Bispo Santos ${ }^{[1]}$, Andrea Gomes Santana Melo ${ }^{[1]}$, \\ Álvaro Silva Lima ${ }^{[2]}$, Camila Dantas Carvalho ${ }^{[1]}$, Silmara Marques Allegretti ${ }^{[3]}$, \\ Cláudia Moura de Melo ${ }^{[1],[4],}$ Rubens Riscala Madi ${ }^{[1],[4]}$ \\ and Verônica de Lourdes Sierpe Jeraldo ${ }^{[1],[4]}$
}

[1]. Laboratório de Doenças Infecciosas e Parasitárias, Instituto de Tecnologia e Pesquisa, Aracaju, SE. [2]. Laboratório de Pesquisa em Alimentos, Instituto de Tecnologia e Pesquisa, Aracaju, SE. [3]. Instituto de Biologia Animal, Universidade Estadual de Campinas, Campinas, SP. [4]. Núcleo de Pós-Graduação em Saúde e AmbienteUniversidade Tiradentes, Aracaju, SE.

\begin{abstract}
Introduction: Our objective was to evaluate the influence of rainfall regime on the population dynamics of Biomphalaria in a potential urban focus of schistosomiasis in Aracaju, Brazil, during 2009-2010. Methods: Snails were collected monthly and were counted, measured and identified; the level of infection and fecal contamination at the sampling sites was determined; rainfall data were obtained. Results: High levels of fecal contamination were observed, and the abundance of Biomphalaria glabrata increased during the rainy and post-rainy seasons. The snails' size was variable, and infected snails were identified independently of rainfall. Conclusions: These results provide evidence of anthropogenic and climate interference in an urban focus of schistosomiasis in the Aracaju metropolitan area.
\end{abstract}

Keywords: Biomphalaria glabrata. Sergipe. Urban environment.

Brazil has a high prevalence of schistosomiasis mansoni, which is endemic in 19 states. It is estimated that approximately eight million individuals are infected ${ }^{1}$. Freshwater snails of the genus Biomphalaria participate in the life cycle of Schistosoma mansoni, for which Biomphalaria glabrata is the most important vector species in northeastern Brazil2 .

The establishment and maintenance of new transmission foci of the disease are related to poor socio-environmental conditions and the presence of Biomphalaria snails. Additionally, rural exodus and rural tourism combined with environmental changes have driven the urbanization of this parasitic infection. Belo Horizonte, Maceió, Salvador, Recife and Aracaju are among the Brazilian state capitals in which foci of schistosomiasis are present in urban areas ${ }^{3,4}$.

The objective of this study was to evaluate the influence of the rainfall regime on the population dynamics of Biomphalaria sp. during the period 2009-2010 in a potential urban focus of schistosomiasis. The aim of this study was to obtain information that can be used to obtain grants for the effective planning and implementation of control measures for endemic schistosomiasis.

\footnotetext{
Address to: Dra. Verónica Sierpe Jeraldo. LDIP/ITP. Av. Murilo Dantas 300, Bairro Farolândia, 49032-490 Aracaju, SE, Brasil.

Phone: 5579 3218-2230

e-mail: veronica_sierpe@hotmail.com

Received 19 December 2011

Accepted 11 May 2012
}

The municipalities of Nossa Senhora do Socorro and São Cristóvão are located in the Aracaju metropolitan area.

Collection sites were selected according to information provided by the Schistosomiasis Control Program. The snails were harvested between January 2009 and December 2010. The snail specimens were counted, and the diameter of the shell was measured at its widest point. A sample of four snails from each collection area was randomly chosen for identification ${ }^{4}$.

After $48 \mathrm{~h}$, the collected snails were individually exposed to incandescent light to observe cercariae elimination. This procedure was repeated weekly for three consecutive weeks to determine the absence or presence of $S$. mansoni infection.

A water sample was taken at each collection point during the pre- and post-rainy periods. The levels of fecal and thermotolerant coliform bacteria were determined by the multiple-tube method and compared with the limits set by the Conselho Nacional do Meio Ambiente (CONAMA) Resolution $357^{5}$ (freshwater considered fit for bathing and leisure).

Precipitation data and rainfall patterns were obtained from the Secretary of Water Resources. The rainfall distribution is as follows: January, February and March are considered lowrainfall months (the pre-rainy season); April, May, June and July are high-rainfall months (the rainy season); and the remaining five months are low-rainfall months (the post-rainy season).

Analysis of variance (ANOVA) tests were performed at a 5\% significance level between the groups of snails collected during each rainfall period. The Tukey test was used to determine 
significant mean values. Pearson's correlation coefficient was applied to evaluate possible correlations between abundance and rainfall regime.

Both study sites are considered to be marginal slum areas; wastewater is dumped into ditches near houses, forming a network of open sewers. The snail vectors are fed and infected by waste released into ditches and form foci around residential dwellings. The first area studied is located in the municipality of Nossa Senhora do Socorro, specifically, in the Parque dos Faróis residential, a location that is greatly affected by the Poxim River during the rainy season. The second area corresponds to the Baixa da Divinéia region in the municipality of São Cristóvão, and flooding occurred in the collection area during the rainy season.

Depending on their proximity to the water, small walkways made of wood or concrete slabs can retain the snails that have accumulated around them during rainfall; snails were collected from these ditches and streams. Evaluation of the internal structures of the snails allowed us to identify them as the species Biomphalaria glabrata.

The water analysis for the Parque dos Faróis residential area showed a total coliform index of $2.2 \times 10^{4}$ most probable number per $100 \mathrm{ml}(\mathrm{MPN} / 100 \mathrm{ml})$ in the dry season and $7.9 \times 10^{5}$ MPN/100ml during the rainy season, which are both greater than the recommended levels 5 . In the Baixa da Divinéia region, water analysis showed fecal coliform bacteria levels of $1.7 \times 10^{2} \mathrm{MPN} / 100 \mathrm{ml}$ during the dry season and $1.0 \times 10^{7}$ MPN/100ml during the rainy season (the latter value is above the recommended level ${ }^{5}$ ). There was an increase in fecal coliform bacteria levels during the rainy season at both sampling sites.
Snails infected with $S$. mansoni were found at both study sites independent of rainfall patterns, with a higher prevalence in the municipality of São Cristóvão (Table 1).

In the municipality of São Cristóvão, 7,544 snails were collected, which was the largest number collected during the post-rainy season (Table 1 and Figure 1A). Although there was a tendency for snails to be more abundant in the rainy and post-rainy season, this correlation was not statistically significant.

In the Parque dos Faróis residential area, we collected a total of 12,396 snails, and the number of snails collected during the 2010 pre-rainy season was almost double that collected in 2009. Comparing the rainy and post-rainy seasons, we found that the number of snails collected was higher in 2009 for both seasons (Table 1 and Figure 1B).

The differences between the diameters of snails collected in the Parque dos Faróis residential area during the pre-rainy/ rainy seasons in 2009 and the rainy/post-rainy seasons in 2010 were not statistically significant ( $p>0.05)$, but the diameters were significantly different for the remaining rainfall seasons $(\mathrm{p}<0.05)$ (Figure 2A).

In the Baixa da Divinéia region, snail diameters also did not follow a discernible pattern (Figure 2B). Diameters during the 2009 pre-rainy season were significantly larger than in other seasons $(\mathrm{p}<0.05)$.

Our collection of B. glabrata in these areas emphasizes the epidemiological importance of this species as one of the most important vectors of schistosomiasis along the northeastern coast of Brazil ${ }^{6}$.

TABLE 1 - Biomphalaria glabrata snails collected during 2009 and 2010. Prevalence of positive snails during the pre-rainy, rainy and postrainy seasons in the Parque dos Faróis residential area, municipality of Nossa Senhora do Socorro, State of Sergipe, Brazil, and the Baixa da Divinéia community, municipality of São Cristóvão, State of Sergipe, Brazil.

\begin{tabular}{|c|c|c|c|c|c|}
\hline \multirow[b]{2}{*}{ Municipality } & \multirow[b]{2}{*}{ Year } & \multirow[b]{2}{*}{ Rainfall patterns } & \multirow[b]{2}{*}{ Collected total } & \multicolumn{2}{|c|}{ Positive total } \\
\hline & & & & $\mathrm{n}$ & $\%$ \\
\hline \multirow[t]{4}{*}{ Nossa Senhora do Socorro } & 2009 & pre-rainy & 1,152 & 17 & 1.5 \\
\hline & & rainy & 3,036 & 32 & 1.1 \\
\hline & & post-rainy & 2,543 & 24 & 0.9 \\
\hline & & post-rainy & 1,658 & 35 & 2.1 \\
\hline Total & & & 12,396 & 173 & 1.4 \\
\hline \multirow[t]{3}{*}{ São Cristóvão } & 2009 & pre-rainy & 99 & 3 & 3.0 \\
\hline & & rainy & 1,194 & 38 & 3.2 \\
\hline & & post-rainy & 2,066 & 71 & 3.4 \\
\hline Total & & & 7,544 & 203 & 2.8 \\
\hline
\end{tabular}




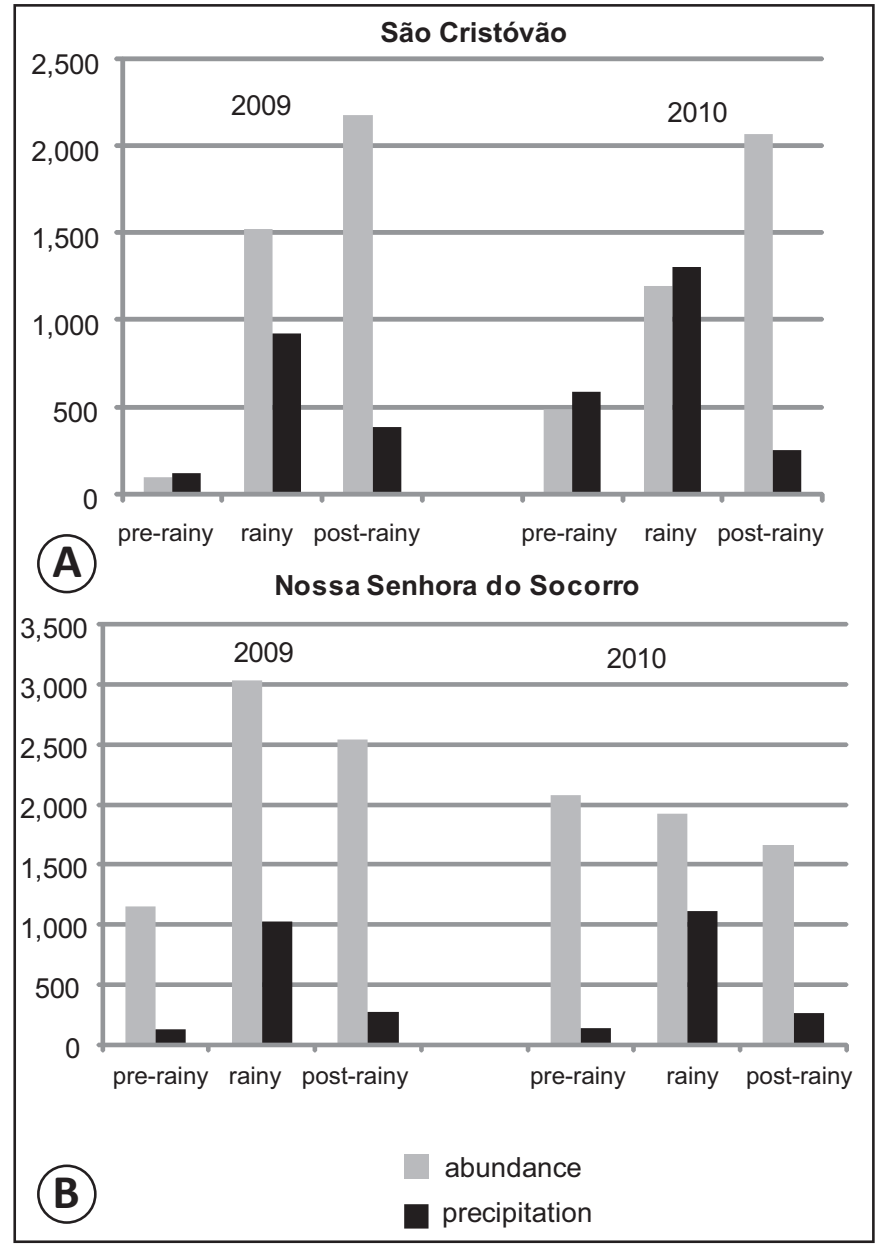

FIGURE 1 - Total number of Biomphalaria glabrata snails collected and precipitation $\left(\mathrm{mm}^{3}\right)$ during the rainy seasons from January 2009 to December 2010. A: Baixa da Divinéia community, municipality of São Cristóvão, State of Sergipe, Brazil. B: Parque dos Faróis residential area, municipality of Nossa Senhora do Socorro, State of Sergipe, Brazil.

The presence of fecal coliform bacteria shows that the collection areas are subject to contamination, likely due to a lack of sanitation. Moreover, the increase in fecal coliform bacteria in the two areas, especially during the rainy season, can be explained by overflowing septic tanks. The presence of infected snails indicates that endemic schistosomiasis is established in both communities, strengthening the evidence for urban foci of schistosomiasis in the Aracaju metropolitan area. The decrease in the total number of snails and the total number of infected snails during the rainy season may be explained by the increased rainfall, which causes ditches to overflow, floods the streets and carries snails to distant locations. This phenomenon allows for the dispersal of infected snails, which can expose residents living outside known foci to $S$. mansoni and lead to the establishment of new foci ${ }^{3}$.

The snail population fluctuated throughout the study period; the snails' numbers normally peak during the rainy season, when washed-in snails appear and begin to reproduce, as has been noted by other authors ${ }^{2,7}$. During the study period, the number of snails was influenced by rainfall patterns, although

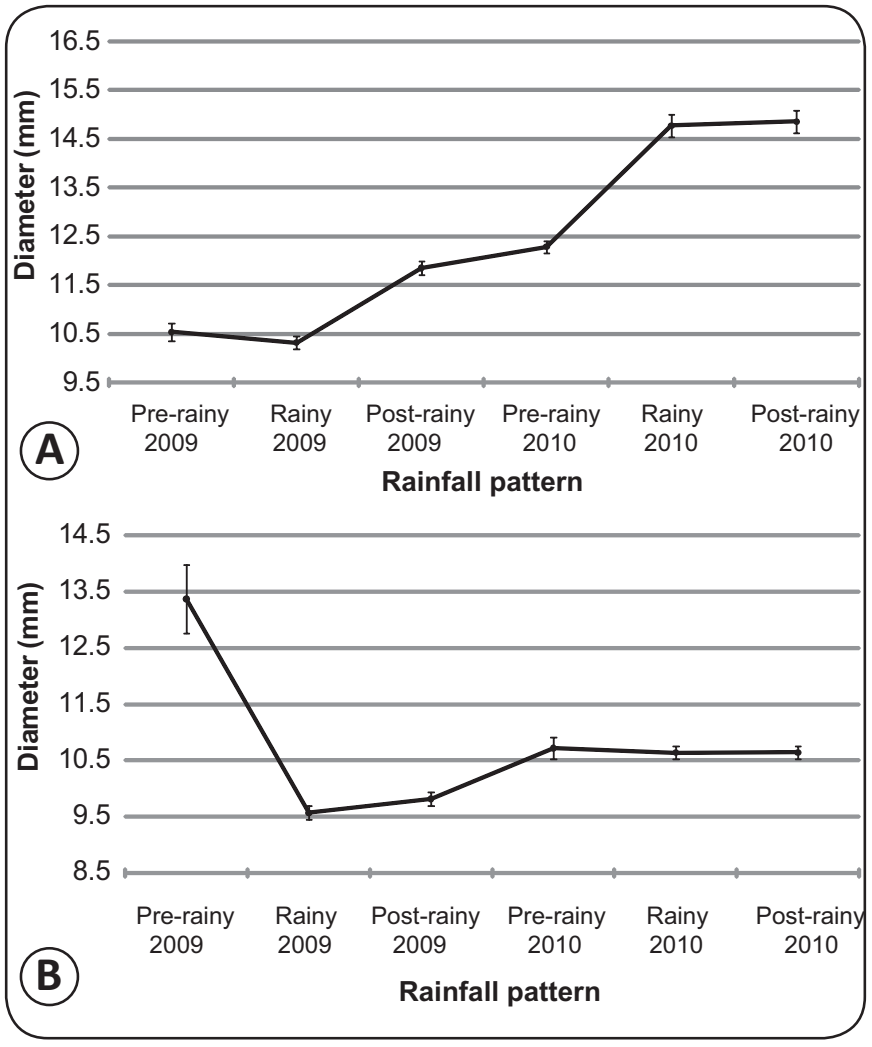

FIGURE 2 - Diameter in millimeters(mm) of the Biomphalaria glabrata snails collected according to the rainfall pattern from January 2009 to December 2010. A: Parque dos Faróis residential area, municipality of Nossa Senhora do Socorro, State of Sergipe, Brazil. B: Baixa da Divinéia community, municipality of São Cristóvão, State of Sergipe, Brazil.

other external factors, such as the cleaning of the ditches and canals by residents before and during the rainy season, may have altered the abundance of snails.

Data on the size of the schistosomiasis-transmitting snails are important for understanding population dynamics under natural conditions $s^{7,8}$ because smaller snails are more susceptible to $S$. mansoni infection.

The data presented in this report show that the diameter of the snails does not follow a particular pattern, which is most likely a result of human intervention and weather conditions. A tendency to find smaller snails was observed during the rainy and post-rainy seasons, which can be explained by the high levels of reproduction observed during this period.

Schistosomiasis mansoni demonstrates an ability to expand in spite of control efforts; undoubtedly, the complex nature of establishing new foci is influenced by the interactions between humans and snail vectors and by the abiotic factors that clearly influence the population dynamics of Biomphalaria ${ }^{7}$.

Behavioral changes in Biomphalaria that are associated with its establishment in urban areas have been the primary cause of the spread of schistosomiasis. A lack of infrastructure, such as paved streets and sidewalks, enables the accumulation of water and the growth of vegetation, which create environments that support the proliferation of snails. A lack of sanitation leads 
to the contamination of these areas with human fecal matter, which can result in snail infection ${ }^{6}$. This situation has been observed in different cities in Brazil, where the importance of infections in the areas immediately surrounding residences has been emphasized ${ }^{9,11}$.

Water analysis showed high levels of fecal coliform bacteria contamination in the study areas, providing evidence that the ditches intended to drain storm water are also being used as sewage ditches. Thus, the residents of both study areas are constantly being exposed to infectious agents.

Although schistosomiasis control manuals are clear regarding surveillance methods and vector control, the effectiveness of these measures depends on an understanding of the ecology and behavior of these snails and their role in the local epidemiology ${ }^{10,12}$.

This report highlights the importance of studies at the local level for understanding the processes that generate health hazards, as efficient control of schistosomiasis may depend on understanding environmental, ecological and behavioral questions related to its intermediate host.

\section{CONFLICT OF INTEREST}

The authors declare that there is no conflict of interest.

\section{FINANCIAL SUPPORT}

Edict Ministério da Saúde/Conselho Nacional de Desenvolvimento Científico e Tecnológico/Fundação de Apoio à Pesquisa e à Inovação Tecnológica do Estado de Sergipe (MS/ CNPq/FAPITEC/SE) 06/2008).

\section{REFERENCES}

1. Pordeus LC, Aguiar LR, Quinino LRM, Barbosa CSA. Ocorrência das formas aguda e crônica da esquistossomose mansônica no Brasil no período de 1997 a 2006: uma revisão de literatura. Epidemiol Serv Saude 2008; 17:163-175.
2. Souza MAA, Barbosa VS, Wanderlei TNG, Barbosa CS. Criadouros de Biomphalaria, temporários e permanentes, em Jaboatão dos Guararapes, PE. Rev Soc Bras Med Trop 2008; 41:252-256.

3. Araújo KCGM, Resendes APC, Souza-Santos R, Silveira Júnior JC, Barbosa CS. Análise espacial dos focos de Biomphalaria glabrata (Say, 1818) e de casos humanos de esquistossomose mansônica em Porto de Galinhas, Pernambuco, Brasil, no ano 2000. Cad Saude Publica 2007; 23:409-417.

4. Lima LC. Família Planorbidae. In: Barbosa FS, editor. Tópicos em Malacologia Médica. Rio de Janeiro: Fundação Oswaldo Cruz; 1995. p. $90-112$.

5. Conselho Nacional do Meio Ambiente (CONAMA). Resolução CONAMA $\mathrm{n}^{\circ} 357$, de 17 de março de 2005. [Cited 2011 February 23]. Available from: http://www.cetesb.sp.gov.br/Agua/praias/res_conama_357_05.pdf.

6. Souza MAA, Barbosa VS, Albuquerque JO, Bocanegra S, Souza-Santos $\mathrm{R}$, Paredes H, et al. Aspectos ecológicos e levantamento malacológico para identificação de áreas de risco para transmissão da esquistossomose mansoni no litoral norte de Pernambuco, Brasil. Iheringia Serie Zoológica 2010; 100:19-24.

7. Barbosa FS, Barbosa CS. The bioecology of snails vectors for schistosomiasis in Brazil. Cad Saude Publica 1994; 10:200-209.

8. Fernandez MA, Thiengo SC. Susceptibility of Biomphalaria straminea from Peixe Angical dam, Tocantins, Brazil to infection with three strains of Schistosoma mansoni. Mem Inst Oswaldo Cruz 2010; 105: 488-491.

9. Barbosa CS, Domingues ALC, Abath F, Montenegro SML, Guida U, Carneiro J, et al. Epidemia de esquistossomose aguda na praia de Porto de Galinhas, Pernambuco, Brasil. Cad Saude Publica 2001; 17:725-728.

10. Rollemberg CVV, Santos CMB, Silva MMBL, Souza AMB, Silva AM, Almeida, JAP, et al. Aspectos epidemiológicos e distribuição geográfica da esquistossomose e geo-helmintos, no Estado de Sergipe, de acordo com os dados do Programa de Controle da Esquistossomose. Rev Soc Bras Med Trop 2011; 44:91-96.

11. Barbosa CS, Montenegro SML, Abath FG, Domingues ALC. Eventos epidemiológicos relacionados à transmissão da esquistossomose em áreas rurais e urbanas de Pernambuco. Mem Inst Oswaldo Cruz 2002; 96: 169-172.

12. Ministério da Saúde. Departamento de Vigilância Epidemiológica. Vigilância e controle de moluscos de importância epidemiológica: diretrizes técnicas. Programa de Vigilância e Controle da Esquistossomose (PCE). $2^{\text {nd }}$ ed. Brasília: Ministério da Saúde; 2008. 